\title{
INFECTION AND COLONIZATION BY GRAM-NEGATIVE BACILLI IN NEONATES HOSPITALIZED IN HIGH RISK NURSERY AT UBERLANDIA FEDERAL UNIVERSITY HOSPITAL: ETIOLOGY, RESISTANT PHENOTYPES AND RISK FACTORS
}

\author{
Renata Cristina Cezário ${ }^{1 *}$; Rosineide Marques Ribas ${ }^{1}$; Vânia Olivetti Steffen Abdallah² ${ }^{2}$ Claudia Lúcia Carneiro²; \\ Paulo P. Gontijo Filho ${ }^{1}$ \\ ${ }^{1}$ Laboratório de Microbiologia da Universidade Federal de Uberlândia, Uberlândia, MG, Brasil; ${ }^{2}$ Berçário de Alto Risco do \\ Hospital da Universidade Federal de Uberlândia, Uberlândia, MG, Brasil
}

Submitted: October 15, 2003; Returned to authors for corrections: February 03, 2004; Approved: September 27, 2004

\begin{abstract}
The aims of this study were to determine endemic and epidemic infection due to Gram-negative bacilli, risk factors associated with colonization and infection by these organisms and the resistance phenotypes (ESBL, AmpC) in neonates admitted in a High Risk Nursery. The study was conducted during a 21 month period and included: a prospective study to evaluate the neonates with hospital infection and the use of third-generation cephalosporins; a case-control study to determine the risk factors associated with colonization/infection. Rectal and oropharynx cultures were also performed in four opportunities (September and November 2001, February and August 2002). The isolates for which the resistance of ceftazidime was $2 \mu \mathrm{g} / \mathrm{mL}$ were suspected of producing ESBL or AmpC $\beta$-lactamases. The incidence of infection by Gram-negative bacilli was $2.4 \%$ (89/ 3.708 neonates), and sepsis (35.9\%) and conjunctivitis (31.4\%) were the most common infections. The endemic infections were more prevalent $(73.9 \%)$ and usually associated with Enterobacteriaceae (95.5\%), being these organisms also related to colonization, corresponding mainly to isolates of Enterobacter spp. and Klebsiella spp. Two outbreaks of Pseudomonas aeruginosa $(\mathrm{n}=10)$ and Acinetobacter baumannii $(\mathrm{n}=11)$ were identified during the survey. Univariate analysis showed that risk factors for Gram-negative bacilli infection considered significant included: the length of stay before infection/colonization, exposure to antimicrobial agents, mechanical ventilation, central venous catheters, parenteral nutrition and surgery. The majority of resistance to ceftazidime among Enterobacteriaceae isolates (80.9\%) was from ESBL phenotype. Administration of thirdgeneration cephalosporins (ceftriaxone) led to the emergence of these multiresistant Gram-negative bacilli in the neonatal unit.
\end{abstract}

Key words: infection, colonization, neonates, Gram-negative bacilli, resistance phenotype

\section{INTRODUCTION}

Nosocomial infections are associated with substantial morbidity and mortality and have become a matter of major concern in Neonatal Intensive Care Units (NICU) and High Risk Nursery (HRN) $(23,24)$. The main predisposing factors associated with these infections are low birth weight, length of time spent in hospital, invasives procedures, surgery and also colonization by bacteria from hospital environment $(1,6)$.

The most common organisms related to these infections are Gram negative-bacilli (GNB) particularly members of the family Enterobacteriaceae as Escherichia coli, Enterobacter spp., Klebsiella spp. and Pseudomonas aeruginosa and Acinetobacter baumannii $(1,6,24)$. Organisms isolated from patients in

*Corresponding author. Mailing address: Universidade Federal de Uberlândia, Seção de Imunologia, Microbiologia e Parasitologia, Avenida Pará 1720, Umuarama. 38400-902, Uberlândia, MG, Brasil. Telefax: (+5534) 3218-2332. E-mail:cezariorenata@ yahoo.com 
intensive care units are more likely to be resistant to antibiotics than those isolated from general-ward patients, probably because there selective pressure exerted by antibiotics in these units $(1,23)$. Although several biochemical mechanisms may explain $\beta$-lactam resistance among GNB, $\beta$-lactamases synthesis is the most important (15). Resistance appeared initially in organisms such as Enterobacter cloacae, Citrobacter freundii, Serratia marcescens and P. aeruginosa, due to overproduction of chromosomal AmpC $\beta$-lactamase thus provide resistance to both oxyimino- and $7-\alpha$-methoxycephalosporins and monobactans, and late on plasmids encoding extended-spectrum $\beta$-lactamases (ESBL). Cephamycins as cefoxitin are not affected by these enzymes that are blocked by $\beta$-lactamase inhibitors, and are described mainly in K. pneumoniae and E. coli $(17,19)$.

The purpose of this study was to determine endemic and epidemic infection due to Gram-negative bacilli, risk factors associated with colonization and infection by these organisms and the presence of resistance phenotypes (ESBL, AmpC) in neonates admitted in a High Risk Nursery.

\section{MATERIALS AND METHODS}

\section{Hospital and study design}

The High Risk Nursery of the Hospital de Clínicas of Universidade Federal de Uberlândia (HRN-HC-UFU) has 45 beds divided into the following rooms: Neonatal Intensive Care I and II, High Risk Unit, Intermediate Care I and II, Isolation, Admission and Extern. From January 2001 to September 2002 a prospective laboratorial surveillance was conducted for all neonates ( 89 neonates) with nosocomial infection by GNB and antibiotic treatment with third-generation cephalosporins. We also under took four cross-sectional surveys in order to determine the prevalence of 85 neonates colonized with GNB in September and November 2001, February and August 2002. During this period data regarding the predisposing factors (birth weight, length of stay, vascular catheters, mechanical ventilation, antibiotic therapy, surgery, parenteral nutrition) associated with either an increased risk of colonization or infection was recorded on a individual form.

\section{Screening, identification and susceptibility tests}

Oropharynx and rectal specimens were obtained with swabs of all newborns during the four cross-sectional studies and were inoculated onto MacConkey agar with and without $2 \mu \mathrm{g} /$ $\mathrm{mL}$ of ceftazidime. Isolates were identified by conventional biochemical tests (8), and their antimicrobial susceptibility was evaluated by disk-diffusion method according to NCCLS guidelines (16). ESBL production was detected on isolates by the double-disk synergy test using ceftazidime $(30 \mu \mathrm{g})$, aztreonam $(30 \mu \mathrm{g})$ and amoxicillin/clavulanate $(20 / 10 \mu \mathrm{g})(10)$. AmpC phenotype was defined as third-generation cephalosporins and cefoxitin resistant and the resistance was not reverted by clavulanate (17).

\section{Statistical analysis}

All data were analyzed in Epi-Info version 5.0. Categorical variables were compared using the $\mathrm{X}^{2}$ or when appropriate Fisher's exact test. Relative Risk (RR) and 95.0\% confidence intervals ( $\mathrm{CI}_{95}$ ) were calculated (3).

The study protocol was approved by HC-UFU Bioethical Research Committee.

\section{RESULTS}

During the 21 months surveillance period GNB nosocomial infection was diagnosed in 89/3.708 neonates accounting for incidence rate of $2.4 \%$ and Enterobacteriaceae strains and nonfermenting GNB represented $40.7 \%$ and $20.4 \%$ of the cultures, respectively (data not shown). Most infections were endemic $(73.9 \%)$ and caused by Enterobacteriaceae (95.5\%). Sepsis (35.9\%), conjunctivitis (31.4\%) and urinary tract infections (17.9\%) were the most common sites of infection. During the study period two outbreaks, one by $P$. aeruginosa multidrugresistant (gentamicin, cefpime and ciprofloxacin) involving ten neonates with seven episodes of conjunctivitis and three of sepsis and other one by A. baumannii when eleven neonates developed sepsis.

Comparison between infected and colonized infants showed significant differences in all measured variables with exception of low birth weight as far as endemic infections were considered (Table 1).

Colonization with GNB was related to infection by these organisms being Enterobacter spp. and Klebsiella spp. the most common agents, with positive rates of $30.8 \%$ for infection and $41.7 \%$ for colonization, and $27.7 \%$ for infection and $17.4 \%$ for colonization, respectively (Table 2). The results of all cultures showed that the intestine was the most frequently (59.0\%) colonized site by Enterobacter spp. and Klebsiella spp. On the other hand, the use of surveillance cultures on HRN did not present evidence for colonization with $P$. aeruginosa and A. baumannii being a prerequisite for subsequent infection.

Among the colonization isolates approximately half (52 of 105 isolates) were resistant to the third-generation cephalosporins and the majority was identified as Enterobacter ssp., antibiotic resistance frequencies are showed in Table 3.

Alltogether, among the cases of either colonization (68/115) or infection (37/64) 58.7\% were harboring third-generation cephalosporins multiresistant GNB isolates with those of Enterobacter spp. and Klebsiella spp. showing similar proportions of resistance to ceftazidime/ceftriaxone.

The prevalence of ESBL and AmpC producers among the 68 isolates of Enterobacteriaceae obtained from colonized neonates 
Table 1. Univariate analysis of 125 neonates with infection or colonization by Gram-negative bacilli in High Risk Nursery at HC-UFU, from January 2001 to September 2002.

\begin{tabular}{lrrrr}
\hline Risk factors & $\begin{array}{c}\text { Colonized } \\
(\mathrm{N}=85) \\
\mathrm{n}(\%)\end{array}$ & $\begin{array}{r}\text { Infected } \\
(\mathrm{N}=40) \\
\mathrm{n}(\%)\end{array}$ & $\mathrm{RR}^{1}(\mathrm{CI})^{2}$ & ${\text { Value } \mathrm{P}^{3}}$ \\
\hline Intrisic & & & & \\
$\begin{array}{l}\text { Length stay }>7 \text { days } \\
\text { Weight }<1500 \mathrm{~g}\end{array}$ & $53(62.4)$ & $39(97.5)$ & $0,59(0.49-0.72)$ & $<0.0001$ \\
Extrinsic & $28(32.9)$ & $17(42.5)$ & $0.87(0.67-1.14)$ & 0.4015 \\
Antimicrobial use & $27(31.7)$ & $38(95.0)$ & $0.43(0.32-0.59)$ & $<0.0001$ \\
$\mathrm{~N}^{\circ} \geq 2$ & $9(10.6)$ & $36(90.0)$ & $0.21(0.12-0.38)$ & $<0,0001$ \\
$\mathrm{~N}^{\circ}<2$ & $18(21.2)$ & $2(10.0)$ & $1.41(1.15-1.73)$ & 0.0413 \\
$3^{\text {rd }} 4^{\text {th}}$ cephalosporins & $3(3.5)$ & $17(42.5)$ & $0.19(0.07-0.55)$ & $<0.0001$ \\
Invasive device: & & & & \\
CVC & $13(15.3)$ & $15(3.5)$ & $0.63(0.41-0.95)$ & 0.0108 \\
$\mathrm{MV}^{5}$ & $9(10.6)$ & $20(50.0)$ & $0.39(0.23-0.68)$ & $<0.0001$ \\
Surgical & $2(2.4)$ & $23(57.5)$ & $0.10(0.03-0.37)$ & $<0.0001$ \\
Parenteral nutrition & $4(4.7)$ & $17(42.5)$ & $0.24(0.10-0.59)$ & $<0.0001$ \\
\hline
\end{tabular}

${ }^{1} \mathrm{RR}=$ Relative Risk;

${ }^{2} \mathrm{CI}=$ Confiance interval;

${ }^{3} \mathrm{P}=\leq 0.05$;

${ }^{4} \mathrm{CVC}=$ Central Venous Catheter;

${ }^{5} \mathrm{MV}=$ Mechanical Ventilation.

Table 2. Gram-negative bacilli isolated from infected and colonized neonates in High Risk Nursery at HC-UFU, from January 2001 to September 2002.

\begin{tabular}{lrrrr}
\hline \multicolumn{1}{c}{ Organism } & \multicolumn{2}{c}{ Infection } & \multicolumn{2}{c}{ Colonization } \\
& $\mathrm{N}$ & \multicolumn{1}{c}{$\%$} & \multicolumn{1}{c}{$\mathrm{N}$} & \multicolumn{1}{c}{$\%$} \\
\hline Enterobacteriaceae & $\mathbf{6 5}$ & $\mathbf{7 0 . 7}$ & $\mathbf{1 1 5}$ & $\mathbf{1 0 0 . 0}$ \\
Enterobacter spp. & 20 & 30.8 & 48 & 41.7 \\
Klebsiella spp. & 18 & 27.7 & 20 & 17.4 \\
Serratia spp. & 11 & 16.9 & 15 & 13.1 \\
Escherichia coli & 11 & 16.9 & 13 & 11.3 \\
Citrobacter spp. & 4 & 6.1 & 9 & 7.8 \\
Others & 1 & 1.5 & 10 & 8.7 \\
GNB non-fermenting & $\mathbf{2 7}$ & $\mathbf{2 9 . 3}$ & - & - \\
Pseudomonas aeruginosa & 13 & 48.2 & - & - \\
Acinetobacter baumannii & 12 & 44.4 & - & - \\
Crysobacterium & 1 & 3.7 & - & - \\
meningosepticum & 1 & 3.7 & - & - \\
Burkholderia cepacia & $\mathbf{9 2}$ & $\mathbf{1 0 0 . 0}$ & $\mathbf{1 1 5}$ & $\mathbf{1 0 0 . 0}$ \\
Total & &
\end{tabular}

${ }^{1}$ Proteus mirabilis, Salmonella spp., Providencia spp., Morganella morganii. was $80.9 \%$ and $19.1 \%$, respectively (Table 3) being ESBL detected mainly in order of frequency in Serratia spp. (91.6\%), Enterobacter spp. (74.2\%) and Klebsiella spp. (70.0\%) and AmpC in Klebsiella spp. (30.0\%) and Enterobacter spp. $(25.8 \%)$.

It was observed a high rate of neonates infected $(40.2 \%)$ with ceftriaxone resistant organisms and colonized $(41.5 \%)$ with cefatzidime resistant organisms (data not shown). The detection of the ESBL and AmpC phenotype was performed, just among isolates associated with colonization due to the difficulties in obtain the strains related to infection in the hospital laboratory. The use of ceftriaxone (units) was associated with a higher risk of colonization by these organisms (Fig. 1).

\section{DISCUSSION}

The purpose of this study was to provide descriptive microbiologic an epidemiologic data concerning to infection and colonization of hospitalized neonates in an almost two-year period. The incidence rate of GNB infection was $2.4 \%$ and Enterobacteriaceae (70.7\%), mainly members of Enterobacter spp. (30.8\%) and Klebsiella spp. $(27.7 \%)$, represented a high proportion of the GNB identified. Nevertheless, it was documented two outbreaks caused by $P$. aeruginosa and A. baumannii, respectively. In

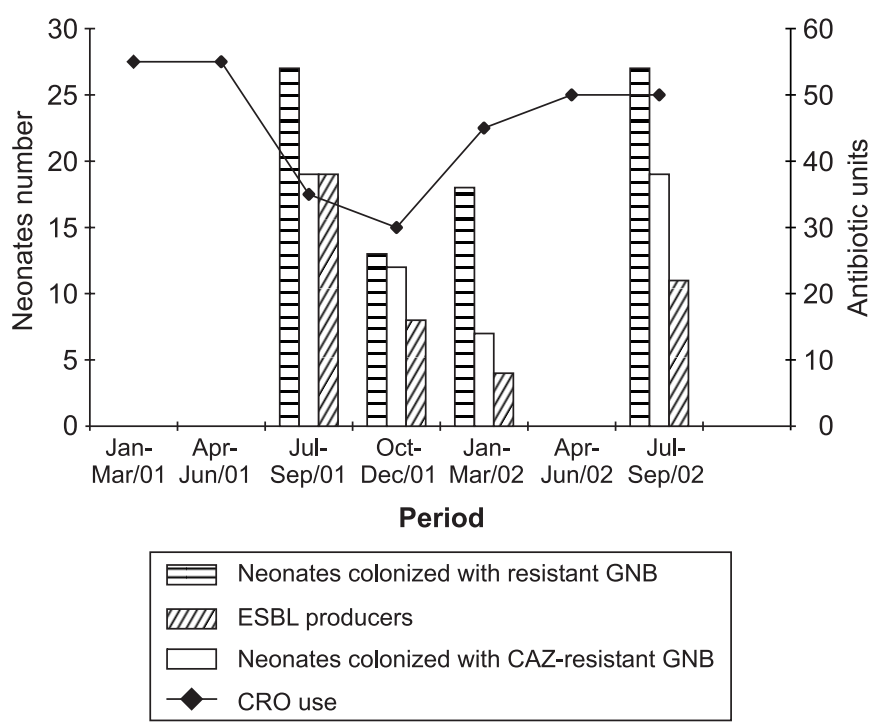

Figure 1. Prevalence of ceftazidime resistant and ESBL producers isolates and ceftriaxone use in neonates in High Risk Nursery at HC-UFU, from January 2001 to September 2002. 
Table 3. Prevalence of $\beta$-lactamases producers phenotypes among Enterobacteriaceae resistant isolates in neonates infected and colonized in High Risk Nursery at HC-UFU, from January 2001 to September 2002.

\begin{tabular}{|c|c|c|c|c|c|c|c|c|}
\hline \multirow{4}{*}{ Organism } & \multirow{3}{*}{\multicolumn{2}{|c|}{$\begin{array}{c}\text { Infection } \\
\mathrm{CRO}^{1} \\
\text { resistant }\end{array}$}} & \multicolumn{6}{|c|}{ Colonization } \\
\hline & & & \multirow{2}{*}{\multicolumn{2}{|c|}{$\begin{array}{c}\mathrm{CAZ}^{2} \\
\text { resistant }\end{array}$}} & \multicolumn{4}{|c|}{ Phenotype } \\
\hline & & & & & \multicolumn{2}{|c|}{ ESBL } & \multicolumn{2}{|c|}{$\mathrm{AmpC}$} \\
\hline & $\mathrm{N}$ & $\%$ & $\mathrm{~N}$ & $\%$ & $\mathrm{~N}$ & $\%$ & $\mathrm{~N}$ & $\%$ \\
\hline Enterobacter spp. & $17 / 20$ & 85.0 & $35 / 48$ & 72.9 & 26 & 47.2 & 9 & 69.2 \\
\hline Klebsiella spp & $10 / 18$ & 55.5 & $10 / 20$ & 50.0 & 7 & 12.7 & 3 & 23.1 \\
\hline Serratia spp. & $4 / 11$ & 36.4 & $12 / 15$ & 80.0 & 11 & 20.0 & 1 & 7.7 \\
\hline Escherichia coli & $3 / 11$ & 27.3 & $5 / 13$ & 38.5 & 5 & 9.1 & - & - \\
\hline Citrobacter spp. & $3 / 4$ & 75.0 & $3 / 9$ & 33.3 & 3 & 5.5 & - & - \\
\hline Others $^{4}$ & - & - & $3 / 10$ & 30.0 & 3 & 5.5 & - & - \\
\hline Total & $37 / 64$ & 57.8 & $68 / 115$ & 59.1 & 55 & 80.9 & 13 & 19.1 \\
\hline
\end{tabular}

${ }^{1}$ Ceftriaxone; ${ }^{2}$ Ceftazidime; ${ }^{3}$ Resistant samples number/Enterobacteriaceae samples total; ${ }^{4}$ Providencia spp. (2), Proteus spp.(2), Morganella morganii (3), Salmonella spp. (3).

spite of only $\sim 5 \%$ of hospital infections occur as part of epidemics (13) in the high-risk nursery area infants have an increased risk of acquiring infection and identification of outbreaks is more frequent as observed in this series $(1,22)$.

The relative frequency of the two most commonly isolated pathogens for endemic infections, Enterobacter spp. and Klebsiella spp. was $35.9 \%$ and $31.5 \%$, respectively, and overall the major sites of nosocomial infections were bloodstream infections $(35.9 \%)$, conjunctivitis $(31.5 \%)$ and urinary tract infections $(17.9 \%)$. These data are in accordance with other US studies $(20,21)$. Pneumonia is the most common nosocomial infection in critical care units, but the limitations and inaccuracies when using only clinical and radiologic criteria and the absence of quantitative culture and microscopic examination of lower respiratory sections justify the conflitant reports. In Brazil, Nagata et al. (14) asserted that lung was the site more likely to be involved in neonates.

Surveillance cultures on neonatal intensive care units may not be a cost effective approach to predicting the organisms responsible for sepsis or will ultimately become ill $(5,7)$, but are crucial in the control and prevention of outbreaks of infection in these units $(2,4)$. Our results suggest that high percentages of colonized babies with Enterobacter spp. $(41.7 \%)$ and Klebsiella spp. (17.4\%) more often than E. coli $(11.3 \%)$ and support the assumption that colonization of the infant precedes infection. The principal reservoir of Gramnegative pathogens in the NICU is the intestinal tract of hospitalized babies, considering that these organisms (Klebsiella spp. and Enterobacter spp.) were also the more frequently ones associated with infection. Nevertheless, rectal swabs would not had sensitivity to detect the two outbreaks strains (P. aeruginosa and $A$. baumannii). Colonization with GNB places hospitalized neonates at risk for development of infections (6). Our results showed that all risk factors analyzed except low birth weight were associated with infection by GNB when compared with colonized neonates. Very low birth weight has been recognized as a factor that predicts neonatal mortality with good discrimination $(1,18)$. In other Brazilian studies $(11,14)$ birth weight, prematurity, low gestational age, mechanical ventilation, total parenteral nutrition, vascular/umbilical catheter, intubation in the delivery room and the use of antibiotics were considered as risk factors associated with nosocomial infections in NICU.

On other hand, Singh et al. (21) reported in a 3year period, that colonized neonates with very low birth weight and those who had received prolonged exposure to antimicrobial agents were at increased risk of GBN infections. Risk factors for colonization/ infection by GNB in neonates included antibiotic therapy $(14,21)$. Exposure to antibiotic therapy is usually high in NICU population, highest in Brazil as observed in this study (52.0\%) and others recent reports by Nagata et al. (46.0\%) (14) and Loureiro et al. (83.0\%) (11) in Londrina and Rio de Janeiro, respectively. Colonization with resistant GNB was related to empiric use of antibiotics in several studies $(1,17)$. In this study, Enterobacteriaceae, especially Klebsiella spp. and Enterobacter spp., that were resistant to third-generation cephalosporins were recovered from most colonized neonates (41.5\%).

Mutiresistant organisms of particular concern are those with plasmid-mediated $\beta$-lactamase (ESBL) and chromossomal (Class I) $\beta$-lactamase $(\mathrm{AmpC})$ and, areas of high antibiotic use are at increased risk of developing these forms of resistance in response to the selective pressure of $\beta$-lactam agents $(4,7,12$, $22,23,25)$. Previous use of third-generation cephalosporins and carbapenem are important risk factors for multiresistant $A$. baumannii and $P$. aeruginosa infections $(9,13)$. Our experience showed that an increase in the use of imipenem to treat neonates infected with $P$. aeruginosa was related with the emergency of the epidemic strain of $A$. baumannii. In this study overall infection and colonization with third-generation cephalosporins resistant GNB was $50.9 \%$ and $41.5 \%$ respectively. There was a high prevalence of ESBL producers among strains of Enterobacter spp. (37.5\%), Serratia spp. (14.3\%) and Klebsiella spp $(8.9 \%)$ isolated from colonized neonates.

The our data suggest that previous recognition of colonized neonates may be helpful in making therapeutic decisions when patients developed signs of infection, show that prevalence of 
ESBL producing Enterobacteriaceae in the unit has increased dramatically in recent years and that the restriction/control use of third/new-generation cephalosporins may be considered to reduce colonization/infection with these multiresistant organisms.

\section{RESUMO}

\section{Infecção e colonização por bacilos Gram-negativos em neonatos internados em Berçário de Alto Risco do Hospital da Universidade Federal de Uberlândia: Etiologia, fenótipos de resistência e fatores de risco}

Os objetivos deste estudo foram determinar infecções endêmicas e epidêmicas por bacilos Gram-negativos, fatores de risco associados a colonização e infecção e a presença dos fenótipos de resistência ESBL e AmpC em neonatos admitidos em Berçário de Alto Risco. Durante um período de 21 meses, foi realizado um estudo prospectivo para avaliar os casos de infecções hospitalares e o uso de cefalosporinas de terceira geração; e um estudo caso-controle para determinar os fatores de risco associados a colonização/infecção. Quatro inquéritos de colonização da orofaringe e intestino dos neonatos (Setembro e Novembro/2001, Fevereiro e Agosto/2002). Amostras com resistência a $2 \mu \mathrm{g} / \mathrm{mL}$ de ceftazidima foram isoladas devido a suspeita de produção de $\beta$-lactamases (ESBL/ AmpC). A incidência de pacientes infectados por bacilos Gram-negativos foi de 2,4\% (89/3.709 neonatos), sendo sepse $(35,9 \%)$ e conjuntivite $(31,4 \%)$ as síndromes mais frequentes. A maioria das infecções foram endêmicas $(73,9 \%)$ e associadas a Enterobacteriaceae $(95,5 \%)$, estes também foram relacionados à colonização, correspondendo principalmente as amostras de Enterobacter spp e Klebsiella spp.. Foram identificados dois surtos, durante o estudo, associados a Pseudomonas aeruginosa $(\mathrm{N}=10)$ e Acinetobacter baumannii $(\mathrm{N}=11)$. Os fatores de risco incluindo: tempo de internação, uso de antimicrobianos, ventilação mecânica, cateter vascular central, cirurgia e nutrição parenteral foram significativos em uma análise univariada e considerados um risco para infecção por bacilos Gram-negativos. A maioria das amostras de Enterobacteriaceae $(80,9 \%)$ com resistência a $2 \mu \mathrm{g} / \mathrm{mL}$ de ceftazidima foram do fenótipo ESBL. O uso de cefalosporinas de terceira geração (ceftriaxona) na unidade neonatal favoreceu a emergência de bacilos Gram-negativos multiresistentes.

Palavras-chave: infecção, colonização, neonatos, bacilos Gramnegativos, fenótipos de resistência

\section{REFERENCES}

1. Calil, R.; Marba, S.T.M.; Tresoldi, A.T. Reduction in colonization and nosocomial infection by multiresistant bacteria in neonatal unit after instituition of educational measures and restriction in the use of cephalosporins. Infec. Control Hosp. Epidemiol., 29(3):133-138, 2001.

2. Danjanovic, V.; van Saene, H.K.; Hart, C.A. Letters to the editor. $J$. Hosp. Infec., 31:73-74, 1995.

3. Dean, A.G.; Dean, J.A.; Burton, A. Epi Info, Versão 5.0: A word processing, database, and statistics program for epidemiology an microcomputers. Stone Montain G.A. USD, Ins; 1995.

4. Dobson, S.R.M.; Isaacs, D.; Wilkinson, A.R.; Hope, P.L. Reduce use of surface cultures for suspected neonatal sepsis and surveillance. Arch. Dis. Child., 67:44-47, 1992.

5. Evans, M.E.; Schaffner, W.; Federspiel, C.F.; Cotton, R.B.; Mckee, K.T.; Strtton, C.W. Sensitivity, specificity and predictive value of body surface cultures in a neonatal intensive care unit. JAMA, 259:248252, 1988.

6. Goldmann, D.A.; Jeanne-Leclair, M.D.; Macone, A. Bacterial colonization of neonates admitted to an intensive care environment. J. Pediatrics, 93(20):288-293, 1978.

7. Isaacs, D.; Wilkinson, A.R.; Moxon, E.R., Surveillance of colonization and late-onset septicemia in neonates. J. Hosp. Infec., 10:114-119, 1987.

8. Isenberg, H.D. Enterobacteriaceae. In: Gorbach, S.L., Bartlett, J.G. Blacklow, N.R. (Eds) Infections Diseases. W.B. Sauders Company, Philadelphia, 1992, p.1463-1478.

9. Kin, G.S.; Devi, S.P.; Mindorff, C.; Patrick, M.L.; Gold, R.; FordJones, E.L. Nosocomial Pseudomonas aeruginosa conjunctivitis in a pediatric hospital. Infect. Control Hosp. Epidemiol., 9(2):77-80, 1988.

10. Livermore, D.M. $\beta$-lactamases in laboratory and clinical resistance. Clin. Microbiol. Rev., 8(4):577-584, 1995.

11. Loureiro, M.M.; De Moraes, B.A.; Quadra, M.R.R.; Pinheiro, G.S.; Asensi, M.D. Study of multi-drug resistant microorganisms isolated from blood cultures of hospitalized newborns in Rio de Janeiro city, Brazil. Braz. J. Microbiol., 33:73-78, 2002.

12. MacDonald, L.C.; Walker, M.; Laretta, C.; Matthew, A.; Aguero, S.M.; Gomez, P.; McNeil, P.; Jarvis, W.R. Outbreak of Acinetobacter spp. bloodstream infections in a nursery associated with contamined aerosols and air conditioners. Ped. Infect. Dis. J., 17:716-722, 1998.

13. MacGowan, J.E.; Metchock, B. Infection Control Epidemiology and Clinical Microbiology. In: Murray, P.R.; Baron, E.J.; Pfaller, M.A.; Tenover, F.C.; Yolken, R.H. (Eds). Manual of Clinical Microbiology. D. C.: ASMPress, Washington, 1995, p.182-189.

14. Nagata, E.; Brito, A.S.J.; Matso, T. Nosocomial infections in neonatal intensive care unit: incidence and risk factors. Infect. Control Hosp. Epidemiol., 30:26-31, 2002.

15. Nathisuwan, S.; Burgess, D.; Lewis, J.S. Extended-spectrum betalactamases: epidemiology, detection, and treatment. Pharmacotherapy, 21(8):920-928, 2001.

16. National Committee for Clinical Laboratory Standards.Perfomance Standards Antimicrobial Disk Susceptibilty tests.Approved Standard $\mathrm{M}_{2}-\mathrm{A}_{5}$ NCCLS, Villanova, PA, 1997

17. Philippon, A.; Arlet, G.; Jacoby, G.A. Plasmid determined AmpCType $\beta$-lactamases. Antimicrob. Agents Chemother, 46(1):1-11, 2002.

18. Pollack, M.M.; Koch, M.A.; Bartel, D.A. et al. A comparison of neonatal mortality risk prediction models in very low birth weight infants. Pediatrics, 105:1051-1057, 2000.

19. Sanders, C.C. Chromosomal cephalosporinases responsible for multiple resistance to newer $\beta$-lactam antibiotics. Ann. Rev. Microbiol., 41:573-593, 1987.

20. Siegel, J.D. The newborn nursey. In: Bennett, J.V.; Brachman, P.S (Eds). Hospital Infections. Lippinott-raven, Philadelphia, 1998, p.403-420.

21. Singh, N.; Patel, K.M.; Leger, M.M.; Short, B.; Sprague, B.M.; Kalu, N.; Campos, J.M. Risk of resistant infections with Enterobacteriaceae 
in hospitalized neonates. Ped. Infect. Dis. J., 21(11):1029-1033, 2002.

22. Toltiz, P.; Blumer, J.L. Antibiotic resistant Gram-negative bacteria in the critical care unit. Pediat. Clinic. North. America., 42(3):687$702,1995$.

23. Vieira, L.A.; Castro, E.A.R.; Duarte, J.L.B.; Pinheiro, S.R.; Suassuna, I.; Pereira, J.A.A. Colonização intestinal de recém-natos por enterobactérias multirrresistentes a antimicrobianos em unidade neonatal. J. Pediatria, 75(2):83-90, 1999.
24. Waggnoer-Fountain, L.A.; Donowitz, L.G. Infection in the newborn. In: Wenzel, R.P. (Eds) Prevention and Control of Nosocomial Infections. Willians \& Wilkins, Baltimore, 1997, p.10191038 .

25. Winokur, P.L.; Canton R.; Casellas, J.M.; Legakis, N. Variações na presença de cepas que expressam um fenótipo da $\beta$-lactamase de espectro estendido e caracterização de isolados proveniente da Europa, das Américas e da Região do Pacifico Oeste. Clin. Infect. Dis., 32(Supp 2) $\mathrm{S} 94-103,2001$ 